\title{
The system of effective management of crop production in modern conditions
}

\author{
Oksana Mamai ${ }^{1, *}$, Velta Parsova $^{2}$, Natalya Lipatova ${ }^{3}$, Julia Gazizyanova $^{4}$, and Igor Mamai ${ }^{1}$ \\ ${ }^{1}$ Department of Management and marketing, Samara State Agrarian University, 446442 Kinel, Samara region, Russia \\ ${ }^{2}$ Department of Land Management and Geodesy, Latvia University of Life Sciences and Technologies, LV-3001 Jelgava, Latvia \\ ${ }^{3}$ Department of Economic theory and Economics of agriculture, Samara State Agrarian University, 446442 Kinel, Samara region, \\ Russia \\ ${ }^{4}$ Department Accounting and statistics, Samara State Agrarian University, 446442 Kinel, Samara region, Russia
}

\begin{abstract}
The main task of production management in agricultural enterprises is to build management systems that ensure that the necessary actions and procedures are performed to obtain a market result from the operation of the enterprise's operating system. The problem of managing crop production is quite relevant today, since most agricultural enterprises, switching exclusively to the production of crop production only, do not comply with the recommended technologies for growing crops, violate the sciencebased foundations of farming, which is associated with the lack of modern material technical base, and the difficult financial and economic situation of most farmsteads and especially insufficient level of managerial work in the field of crop production. Thus, the aim of the study is to develop recommendations for improving the organization and management of crop production in modern business conditions. As a result of the study, an analysis of the effectiveness of the organization and management of crop production at the current stage of development of the Russian economy was conducted; problems were studied, prospects for the development of the crop industry were outlined, recommendations were proposed for improving the agricultural management system, taking into account current economic conditions.
\end{abstract}

\section{Introduction}

Crop production is one of the fundamental branches of agriculture. Crop production is the basis for providing the livestock industry with feed, and the population with food. Also, crop products are used in many industries as raw materials of plant origin, such as food, textile, pharmaceutical, fuel and others.

Crop production is a branch of agriculture, which includes the cultivation of crops in field cultivation, vegetable growing, fruit growing, etc. This industry gives necessary food. Consumer goods manufacturing and food industries gets raw materials. Livestock industry, in turn, uses by-products such as straw, silage, and food industry waste.

Agricultural enterprises have a powerful production potential, despite the difficult conditions of production, caused by high prices for production resources, low attractiveness of rural areas, and difficulties in obtaining loans.

In difficult conditions, domestic agricultural enterprises are forced to introduce innovations to improve the efficiency of organization of production.

As practice shows, the products of domestic agricultural enterprises are in demand among the population, even despite higher prices, due to high costs than foreign producers offer.
This is mainly explained by the fact that domestic producers produce environmentally friendly products, while the production of products uses a minimum amount of preservatives. These circumstances create a demand for agricultural products. Moreover, now the demand for farm agricultural products, as products produced in natural conditions, is growing.

In modern rapidly changing socio-political and economic conditions, the economy faces the task of ensuring not only self-survival, but also the expansion of production.

Thus, the transition to sustainable economic growth and further improvement of the organization of crop production is impossible without promoting the use of science, technology and innovations. For an individual choice of the necessary implementations, an in-depth study of the actual processes of production of the product, its nature, orientation and dynamics, is necessary.

\section{Materials and methods}

The methodological basis of the study was dialectical principles, methods of system analysis of economic phenomena: analysis and synthesis, the method of scientific abstraction, the method of expert evaluation, etc. Research methods include economic analysis and

\footnotetext{
*Corresponding author: mamai_ov@ssaa.ru
} 
statistical analysis. The study is based on data from the Ministry of Economic Development of the Russian Federation, the Ministry of Agriculture of the Russian Federation, and the Federal State Statistics Service.

\section{Results}

As the study showed, crop production in Russia is the country's main agricultural sector. The total volume of crop production in all categories of Russian farms in 2018 in value terms is estimated at 2569.0 billion rubles. (fig. 1).

As it can be seen from Fig. 1, this is not the best indicator for the last 10 years, however, there is a clear tendency to increase the total volume of crop production in value terms

In Russia, more than 400 different types of plants are cultivated, which have a certain economic value. The largest areas are sown with grain crops - spring and winter wheat, barley, oats, rye, corn, legumes and cereals.

Crop production largely determines the welfare of the country's population. A characteristic feature of plant growing is seasonality, depending on weather and natural-climatic conditions [1]. The main tools and means of labor in crop production are the land (Fig. 2) and the plant [2].

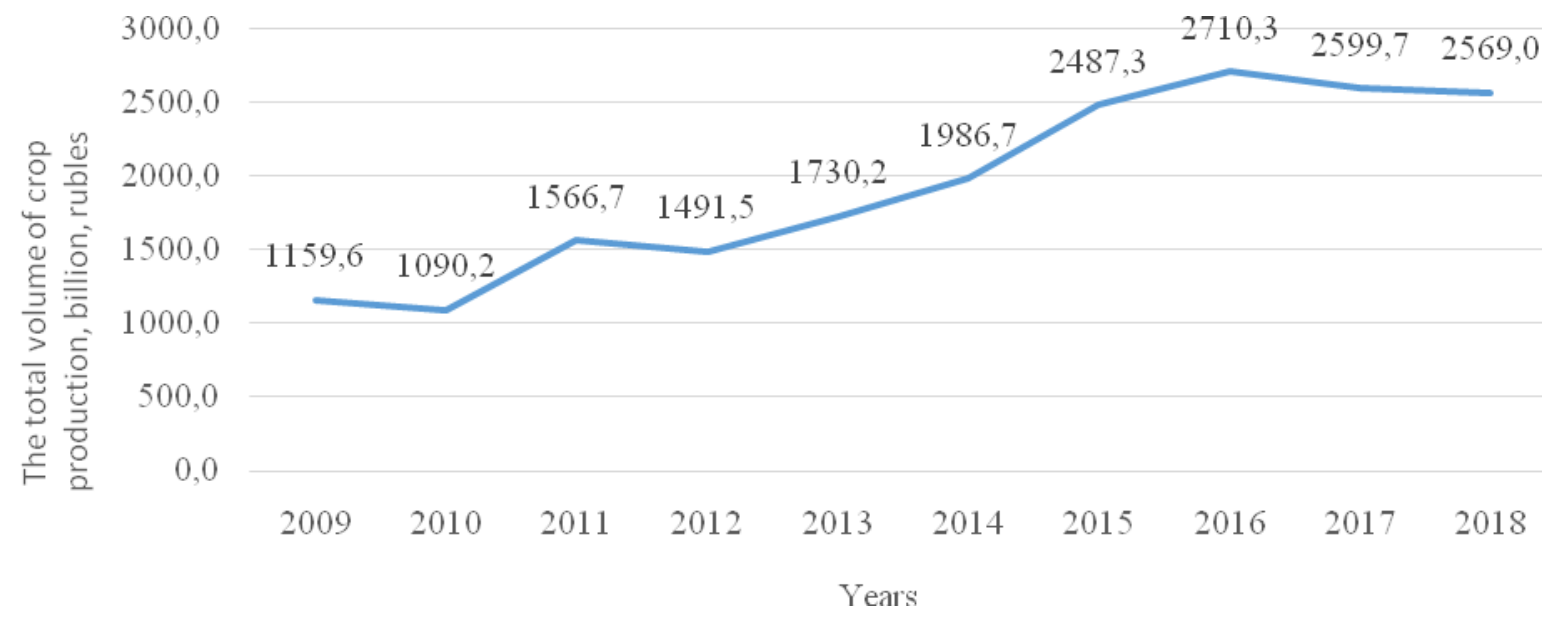

Fig. 1. The total volume of crop production, billion rubles (compiled by the authors based on the materials of the Federal State Statistics Service)

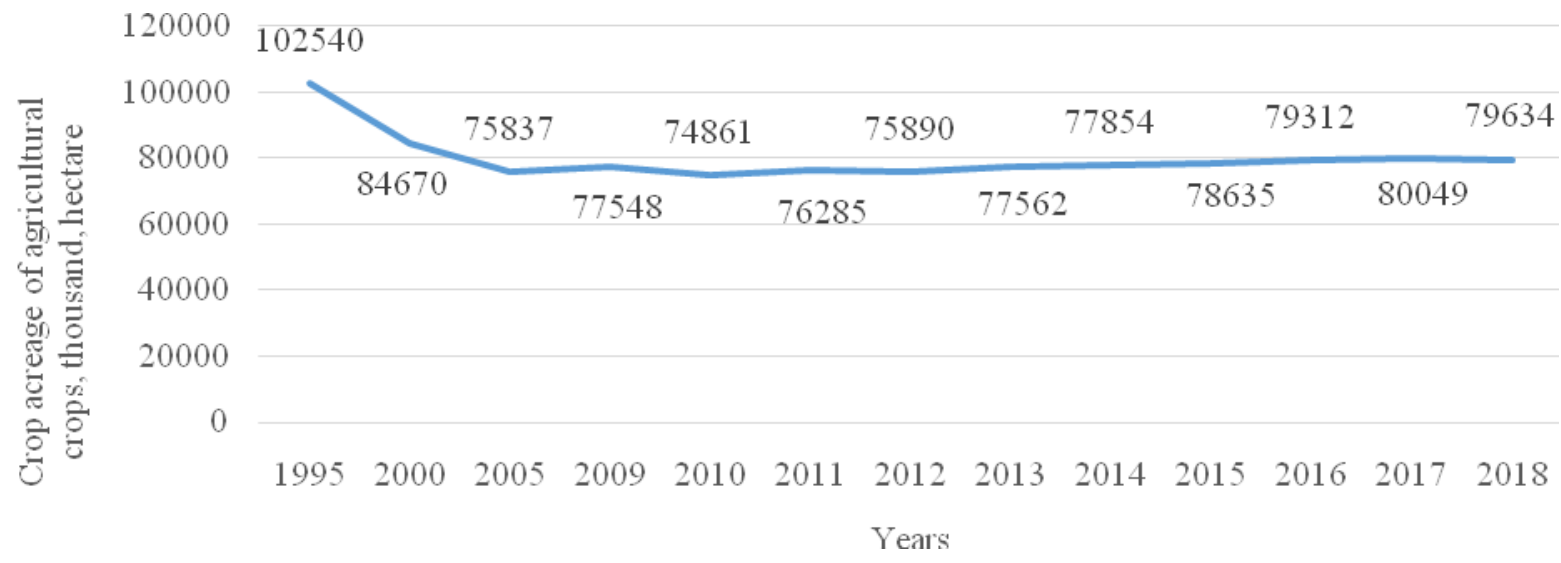

Fig. 2. The total sown area of agricultural crops in the Russian Federation, thousand hectares (compiled by the authors based on the materials of the Federal State Statistics Service)

As for long-term trends, in relation to the period of 24 years ago, the size of the planting area has significantly decreased - by $24.4 \%$. In the late 1990 s, early 2000s. in addition to the reduction in sown areas, the yield per unit area — productivity — fell, which increased the overall decline in the most types of crop.
Since the mid 2000s in addition to restoring the size of cultivated areas, with the introduction of advanced technologies in the growing process, crop yields also increased significantly. For many types of crop production (wheat, sunflower, corn, soybeans, rapeseed, 
rice), gross fees significantly exceeded the indicators of the early 1990s.

Economic importance of crop production is enormous mostly because it provides a person with almost all products of plant origin. Crop is a source of raw materials for the food processing industry.

The main sectors of crop production according to industrial classification can be attributed to the industry for growing grain crops (wheat, barley, rye, corn, buckwheat, rice, sorghum, millet), legumes (peas, beans, lentils, chickpeas), industry for the cultivation of oil crops (sunflower, soy, ginger), sugar crops (in Russia sugar beet), potatoes, vegetables (open field, protected ground), gardening, industry to farming (linen, cotton), fodder crops (table 1).

Table 1. The structure of cultivated areas of the Russian Federation by type of crops (in farms of all categories; as a percentage of the total cultivated area) (compiled by the authors based on the materials of the Federal State Statistics Service)

\begin{tabular}{|l|r|r|r|r|r|r|r|r|r|r|}
\hline \multirow{2}{*}{ Agricultural crops } & \multicolumn{10}{|c|}{ Years } \\
\cline { 2 - 14 } & 2009 & 2010 & 2011 & 2012 & 2013 & 2014 & 2015 & 2016 & 2017 & 2018 \\
\hline All sown area & 100.0 & 100.0 & 100.0 & 100.0 & 100.0 & 100.0 & 100.0 & 100.0 & 100.0 & 100.0 \\
\hline Grain and pulse crops & 61.3 & 57.7 & 57.1 & 58.6 & 59.1 & 59.3 & 59.3 & 59.4 & 59.6 & 58.2 \\
\hline Industrial crops & 11.6 & 14.6 & 15.5 & 14.9 & 15.5 & 15.7 & 16.2 & 17.2 & 17.4 & 19.1 \\
\hline Potato & 2.6 & 2.6 & 2.5 & 2.4 & 2.2 & 2.1 & 2.0 & 1.8 & 1.7 & 1.7 \\
\hline Outdoor vegetables & 0.8 & 0.8 & 0.8 & 0.8 & 0.7 & 0.7 & 0.7 & 0.7 & 0.7 & 0.7 \\
\hline Cucurbitaceous food plants & 0.2 & 0.2 & 0.3 & 0.2 & 0.2 & 0.2 & 0.2 & 0.2 & 0.2 & 0.2 \\
\hline Feed crops & 23.6 & 24.1 & 23.8 & 23.1 & 22.2 & 22.0 & 21.6 & 20.7 & 20.4 & 20.2 \\
\hline
\end{tabular}

In the structure of sown areas of Russia, wheat takes the first place, which in 2018 accounts for one third of all areas (34.2\%). Also, significant areas fall on crops such as barley $(10.5 \%)$, sunflower $(10.2 \%)$, oats $(3.6 \%)$, corn for grain $(3.1 \%)$, oilseeds $(17.5 \%)$, rye $(1.2 \%)$, buckwheat (1.3\%). Fodder crops (annual, perennial grasses, corn for livestock feed, sugar beets for livestock feed, and other crops) occupy a high proportion of the total sown area in crops $-20.2 \%$ of all areas in 2018 .

Grain production of all types in Russia in 2018 amounted to 113,255 thousand tons, which is $14.0 \%$ or $16,230.8$ thousand tons more than 10 years ago (Table 2).

Table 2. Gross harvest of crops in the Russian Federation in farms of all categories, thousand tons (compiled by the authors based on the materials of the Federal State Statistics Service)

\begin{tabular}{|c|c|c|c|c|c|c|c|c|c|c|}
\hline \multirow{2}{*}{ Agricultural crops } & \multicolumn{9}{|c|}{ Years } \\
\cline { 2 - 12 } & 2009 & 2010 & 2011 & 2012 & 2013 & 2014 & 2015 & 2016 & 2017 & 2018 \\
\hline $\begin{array}{c}\text { Cereals and } \\
\text { legumes }\end{array}$ & 97024 & 61007 & 94247 & 70941 & 92419 & 105212 & 104729 & 120677 & 135539 & 113255 \\
\hline $\begin{array}{c}\text { Industrial crops: } \\
\text { sugar beet }\end{array}$ & 24863 & 22241 & 47609 & 45031 & 39292 & 33476 & 38989 & 51325 & 51913 & 42066 \\
\hline Potato & 28429 & 18498 & 27985 & 24542 & 24021 & 24284 & 25406 & 22463 & 21708 & 22395 \\
\hline Outdoor vegetables & 11854 & 10437 & 12470 & 11724 & 11445 & 11552 & 11881 & 11698 & 11979 & 11853 \\
\hline $\begin{array}{c}\text { Cucurbitaceous } \\
\text { food plants }\end{array}$ & 1489 & 1233 & 1647 & 1534 & 1492 & 1531 & 1783 & 1884 & 1815 & 1970 \\
\hline $\begin{array}{c}\text { Feed crops: root } \\
\text { crops (including } \\
\text { sugar beets for } \\
\text { livestock feed) }\end{array}$ & 1114 & 731 & 1055 & 850 & 828 & 725 & 657 & 533 & 484 & 450 \\
\hline
\end{tabular}

The volume of wheat production in Russia in 2018 amounted to 72.136 thousand tons. For 10 years the yield of wheat increased by $17.0 \%$. While the acreage of wheat in the period under review declined by $7.5 \%$. Therefore, the increase in gross yield of wheat and most other crops, it is provided at the expense of growth of productivity $[3,4]$.

The total amount of acreage of plant varieties in Russia in 2018 amounted to 79.6 million hectares. In relation to 2009 , the size of cultivated areas grew by $2.7 \%$.

Economic efficiency of crop production is determined by the system of indicators: productivity, cost, yield per hectare in cash, the gross and net income per hectare of crop, on one rouble of production costs, for one person-hour. In gross output of agriculture, the crop production reaches about $48.0 \%$.

Yield enhancement is the main way to increase grain production and harvesting. In the system of measures ensuring an increase in the yield of grain crops, crop rotation is given great importance. Pure steam takes leading place in the main grain areas to increase [5]. According to the Russian grain research institute, in terms of net steam, the yield of grain crops increases by $40-70 \%$.

A significant factor affecting productivity is the introduction of high-yielding zoned varieties, the use of high-quality seed material. The use of high-yielding 
varieties allows, ceteris paribus, to receive additionally up to $15.0 \%$ of grain per hectare compared to ordinary crops.

The increase in the production of hard and strong wheat, which forms the basis of the food fund, has particular economic importance. Russia has always been famous for the quality of grain. The country has developed industrial technologies for producing durum and strong wheat grains. In recent years, purchases of strong and valuable wheat varieties from agricultural enterprises accounted for only a little more than half of the demand, and hard varieties only one fifth of the need for them. Having lost its position in the world market, Russia is forced to purchase hard and strong wheat varieties abroad.

Grain production is an industry of high mechanization [6-8]. It is less labor intensive than the cultivation of potatoes, vegetables, flax and other crops. Labor costs per hectare of sowing grain crops on average amount to 17-20 person-hours, and at the center of grain - about 1 person-hour.

The use of intensive factors of production increases material, monetary and labor costs per hectare of sowing, however, due to a significant increase in productivity, the cost of labor and funds per unit of output are reduced. Improving the quality of grain, therefore, selling it at higher prices affects the final results of production - increasing profit and profitability of the industry.

As the study showed, the key problem for the industry is still the inaccessibility of long-term loans. Enterprises are forced to lend at an extremely high interest rate for a rather short period of time, which allows them only to survive the season and does not allow them to plan their activities for a long period.

Among the negative features the low investment attractiveness of the agricultural sector as a wholes hould also be noted. It caused by high capital and energy intensity. These and other, often opposing, factors determine the importance of state participation in regulating the agricultural economy in order to create conditions for the investment attractiveness of the agricultural sector, increase its competitiveness and stability in the market, ensure food security, create conditions for the development of rural areas and improve living conditions rural population $[9,10]$.

Features of the agricultural sector also determine the direction of influence of the state. Currently, these areas include:

- provision of agriculture with basic resources: land, capital, labor resources, real estate, necessary for expanded reproduction;

- ensuring social transformations in rural areas, sustainable development of rural territories;

- ensuring the protection of agricultural producers in the foreign market;

- overcoming crisis phenomena, further ensuring the development of market relations in agriculture in combination with state support for agricultural production;

- providing research in the agricultural sector;

- ensuring integration and cooperation.
In recent years, several key areas of state participation in the regulation of agricultural relations have been highlighted:

- the continuation of structural changes in the agricultural sector and the related clarification of the legal status of agricultural production entities (agricultural cooperatives and peasant (farmer) households primarily);

- determination of special conditions for the participation of agricultural producers in financial relations, including taxation and financial support measures for agricultural production participants;

- state regulation of certain types of agricultural activities, which traditionally include plant growing and animal husbandry as the main types of agricultural production, veterinary medicine and land reclamation, seed production, selection activity and some others;

- features of the use of land for agricultural production (primarily the establishment of a special regime of agricultural land). Thus, the current state of affairs in agriculture objectively requires the modernization of the entire management system from the state to the intraeconomic level. As a result of the reforms in the agro-industrial complex management systems, it is possible to restore the former power of this sector, become competitive in the world market and ensure food security of the domestic market.

\section{Conclusion}

The study conducted allowed us to identify the following main strategic objectives for improving the agricultural management system in the Russian Federation:

- it is necessary to develop relevant areas of the agrarian policy of the Russian state, focused on ensuring food independence in the face of new geopolitical challenges;

- it is important to intensify the development and support of innovative activities aimed at technological modernization of agricultural production, increasing the competitiveness of agricultural products of agricultural enterprises of Russia;

- a system of information and consulting activities for the provision of services to agricultural producers requires the development;

- improving the training, retraining and advanced training of personnel - specialists for agricultural organizations, enterprises focused on active entrepreneurial activity, the development of agribusiness, the digital transformation of agriculture;

- it is necessary to develop and implement the legislative and other normative-legal acts on development of organic agriculture, on the organization of domestic food aid, and other topical areas focused on sustainable development of the Russian agrarian sector in the new economic conditions;

- development and real support of agricultural science, including University are required;

- implementation of measures to restore social infrastructure in rural settlements, providing conditions for the formation of the labor potential of agriculture; 
- ensuring rational use and conservation of soil fertility, protection of land of agricultural purpose;

- transference of the Russian agricultural sector to export-oriented development with the aim of entering the world agrofood market;

- strengthening of the state control (supervision) over the quality, biological integrity and safety of agricultural products at the stage of raw materials.

Some of the above strategic objectives are already being solved at present, however, for the effective management of crop production in particular and the development of the agricultural sector of the economy as a whole, a comprehensive solution is needed.

\section{References}

1. O.I. Goryanin, S.N. Shevchenko, V.A. Korchagin, Meteorology and hydrology 6, 106-110 (2018) (In Russ.)

2. V. Parsova, O. Mamai, S. Zudilin, Proc. of $17^{\text {th }}$ Int. Scientific Conf. "Engineering for Rural Development” 17, 624-631 (Jelgava, 2018)

3. V.G. Vasin, A.N. Burunov, A.V. Vasin, V.A. Milyutkin, N.V. Vasina, R.N. Bagautdinov, A.V.
Novikov, Research J. of Pharmaceutical, Biological and Chemical Sciences 5, 1248-1260 (2018)

4. P.A. Chekmarev, S.V. Obushhenko, V.B. Trocz, N.M. Trocz, The achievements of science and technology APK 8, 28-31 (2018) (In Russ.)

5. V.G. Kutilkin, S.N. Zudilin, Agriculture 2, 19-22 (2018) (In Russ.)

6. M.A. Mastepanenko, S.Z. Gabriyelyan, I.N. Vorotnikov, S.V. Mashkov, E.V. Kulaev, Research J. of Pharmaceutical, Biological and Chemical Sciences 6, 1846-1851 (2018)

7. A.M. Petrov, M.A. Kanaev, Yu.A. Savelev, S.A. Vasilev, E.S. Kanaeva, Research J. of Pharmaceutical, Biological and Chemical Sciences 5, 925-934 (2018)

8. V.A. Milyutkin, V.E. Buksman, Machinery and equipment for the village 7, 10-12 (2018) (In Russ.)

9. O. Mamai, R. Nekrasov, V. Parsova, Proc. of the 19 th Int. Scientific Conf. "Economic Science for Rural Development 2018” 47, 189-195 (Jelgava, LLU ESAF, 2018)

10. E.M. Akhmetshin, A.V. Pavlyuk, A.S. Kokorev, T.G. Lazareva, E.I. Artemova, J. of applied economic sciences 8(62), 2309-2322 (2018) 